STATE OF FLORIDA DEPARTMENT OF NATURAL RESOURCES

\author{
BUREAU OF GEOLOGY
}

Robert O. Vernon, Chief

INFORMATION CIRCULAR NO. 64

\title{
REPORT ON GEOPHYSICAL AND TELEVISION EXPLORATIONS IN CITY OF JACKSONVILLE WATER WELLS
}

\author{
By \\ G.W. Leve \\ Prepared by \\ U.S. GEOLOGICAL SURVEY \\ in cooperation with the \\ BUREAU OF GEOLOGY \\ DIVISION OF INTERIOR RESOURCES \\ FLORIDA DEPARTMENT OF NATURAL RESOURCES \\ and the \\ CITY OF JACKSONVILLE, FLORIDA, DUVAL COUNTY
}




\section{INFORMATION CIRCULAR NO. 64}

ERRATA

1. Par. 5, line $3 \ldots \ldots \ldots \ldots$. . . . Ohmmeters should be ohm-meters 


\title{
STATE OF FLORIDA \\ DEPARTMENT OF NATURAL RESOURCES
}

\author{
BUREAU OF GEOLOGY \\ Robert O. Vernon, Chief
}

INFORMATION CIRCULAR NO. 64

\section{REPORT ON GEOPHYSICAL AND TELEVISION EXPLORATIONS IN CITY OF JACKSONVILLE WATER WELLS}

\author{
By \\ G.W. Leve
}

Prepared by

U.S. GEOLOGICAL SURVEY

in cooperation with the BUREAU OF GEOLOGY

DIVISION OF INTERIOR RESOURCES

FLORIDA DEPARTMENT OF NATURAL RESOURCES and the

CITY OF JACKSONVILLE, FLORIDA, DUVAL COUNTY 
Completed manuscript received March 21, 1969

Printed by the

Florida Department of Natural Resources

Division of Interior Resources

Bureau of Geology

Tallahassee 


\section{CONTENTS}

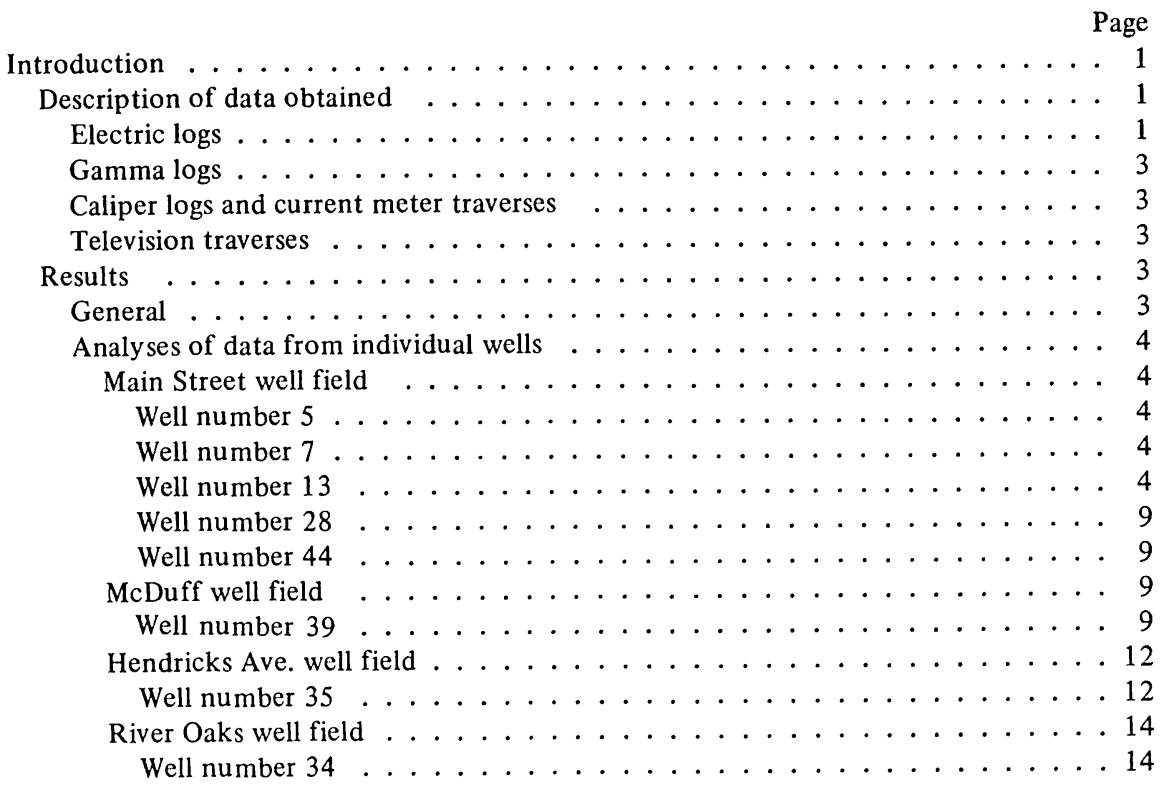

ILLUSTRATIONS

Figure

1. Map showing the location of the wells described in this report . . . . . . . 2

2. Photograph of television image showing caved-in zone at 440 feet in city w ell 5 . View looking vertically down into the hole when the television camera was about 3 feet above the caved-in material. A, back of light source; B, smooth side of well bore; C, material which has collapsed into the open hole . . . . . . . . . 6

3. Geophysical data obtained in well no. $7 \ldots \ldots \ldots \ldots$

4. Geophysical data obtained in well no. $13 \ldots \ldots \ldots$. . . . . . . 8

5. Geophysical data obtained in well no. $28 \ldots \ldots \ldots \ldots$

6. Geophysical data obtained in well no. $44 \ldots \ldots \ldots \ldots 11$

7. Geophysical data obtained in well no. $39 \ldots \ldots \ldots \ldots$. . . . . . . . . . . . . 12

8. Geophysical data obtained in well no. $35 \ldots \ldots \ldots 13$

9. Geophysical data obtained in well no. $34 \ldots \ldots \ldots \ldots$

\section{TABLES}

Table Page

1. Tabulation of data obtained from wells $\ldots \ldots \ldots \ldots \ldots$ 



\section{REPORT ON GEOPHYSICAL AND TELEVISION EXPLORATIONS IN CITY OF JACKSONVILLE WATER WELLS}

by

G. W. Leve

\section{INTRODUCTION}

During November 1968 the U.S. Geological Survey conducted geophysical and television explorations in eight City of Jacksonville water production wells. The purpose of this investigation was to aid the City and the City's consulting engineers (Reynolds, Smith, and Hills) in appraising the physical condition of each well and to gain more information on the hydrologic properties of the aquifer.

The explorations in these wells were made as a part of a comprehensive investigation to fully appraise the water resources in the Jacksonville area. The investigation is being conducted by the U.S. Geological Survey in cooperation with the Division of Geology, Florida Board of Conservation, the City of Jacksonville, and Duval County.

This report describes the findings of the well explorations and includes the basic data obtained from these explorations. The locations of the wells explored are shown on figure 1 .

\section{DESCRIPTION OF DATA OBTAINED}

Conventional well-logging techniques combined with measurements of flow velocity in the borehole can provide valuable information on the geology and water-bearing characteristics of the subsurface rocks penetrated by a well. In addition, the logs and flow velocity traverses obtained from each well can be used to correlate the regional relationship of the rocks. However, the purpose of this report is to present the hydrologic data that was collected during the well explorations and to briefly describe these data to help the City determine the physical condition of the wells. Therefore, a detailed analysis of the data and regional correlations is beyond the scope of this report.

\section{ELECTRIC LOGS}

The different rocks adjacent to a well bore will have varying effects on an artificial electrical current that passes through them. An electric log is a graphic portrayal of the electric current as it passes through the rock. Resistivity logs are graphs of the resistivity of the fluid-saturated rocks expressed in ohmmeters. Spontaneous potential (SP) logs, expressed in millivolts, show the electro-chemical effect of media of different nature (i.e., rocks of different lithology or different texture, or two different types of liquid) and the clectrokinetic effect of fluids moving through permeable rock in a well. Both the 


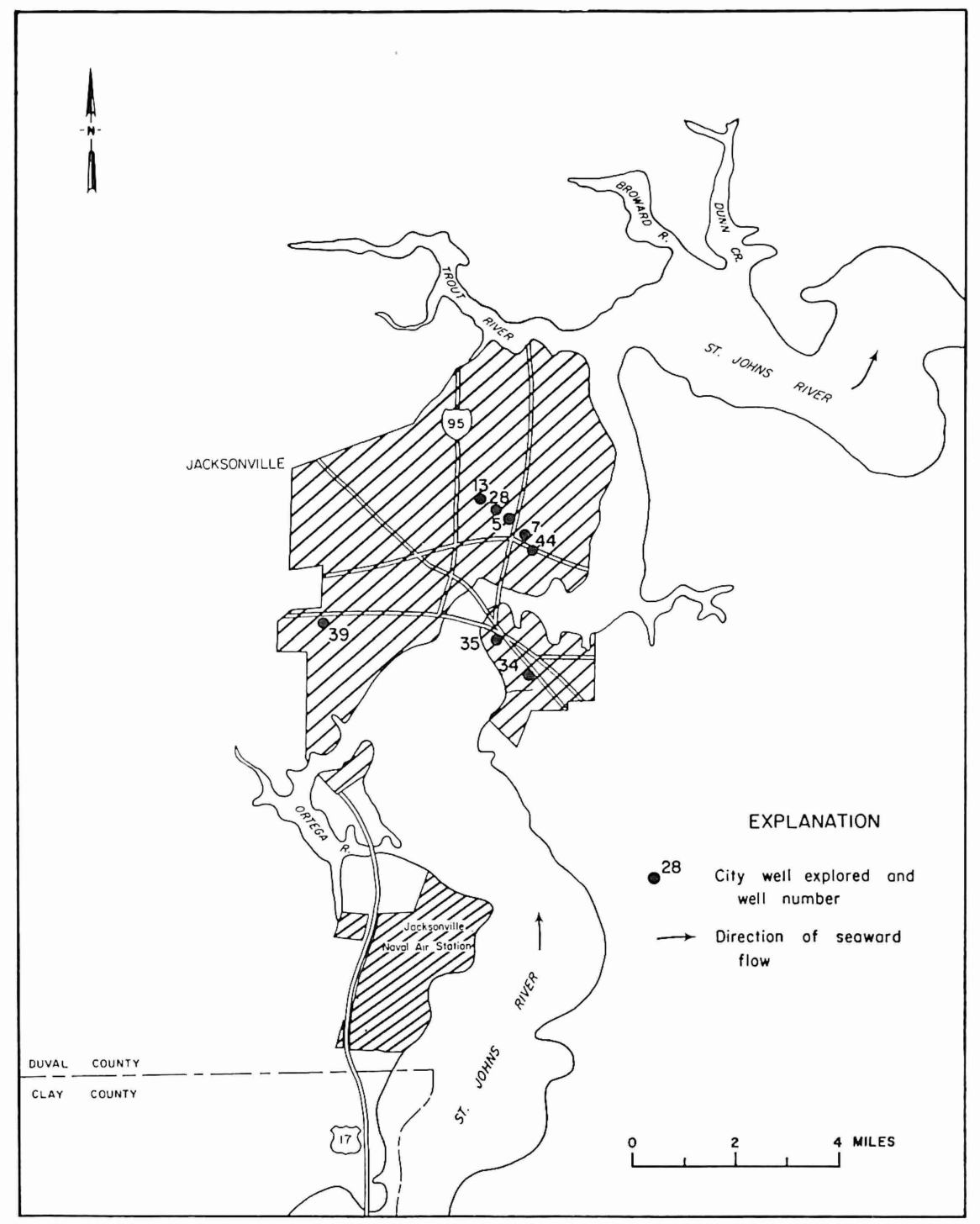

Figure 1. Map showing the location of the wells described in this report.

resistivity logs and spontaneous potential logs can be used to determine the depth of casing in a well, to interpret lithology and permeability of the rocks in a well and to estimate the chemical character of fluid in the pore spaces of the rocks. Correlations of the hydrologic and geologic properties of the rocks can be made throughout the area by comparing the electric logs of each well. The electric log is useful only in the uncased part of the well (open-hole). 


\section{GAMMA LOGS}

The gamma log is a graph of the relative natural gamma radiation of rocks penetrated by the well. Natural gamma radiation is due to the presence of unstable isotopes of uranium, thorium, and potassium and their various decay products within the rocks. The radioactivity is measured by a slowly moving instrument probe which houses a gamma detector, usually a scintillation counter. The gamma log indicates the depth, thickness and lithology of the various types of rocks similar to the electric logs, but it is valuable in determining these characteristics in the cased part of the well which is not possible with an electric log. In general, carbonaceous shales will have a high gamma activity whereas limestone, dolomite and evaporites tend to have low activities.

\section{CALIPER LOGS AND CURRENT METER TRAVERSES}

A caliper $\log$ is a continuous graph of the diameter of the well bore at different depths (cased and uncased parts) and the current meter traverse measures the relative velocity of flow of water at various depths in the well bore. The quantity of water flowing at different depths in the well bore may be calculated by comparing the velocity of flow from the current meter data and the cross-sectional area from the caliper $\log$ at that depth. From this in formation the location, thickness, and yield of the water-bearing zones in the aquifer penetrated by a well may be determined.

\section{TELEVISION TRAVERSES}

An underwater television camera lowered into a well bore affords di ect visual observation of physical conditions in the well. The depth and condition of the casing seat can be determined and any incrustation, cracks and perforations in the casing can be seen and located. Obstructions, cavities or any other irregularities in the open-hole portion of the well can be observed and located. Video tapes of the television traverses can be played back and the video picture compared to electric, gamma, and caliper logs and to current meter data to obtain additional knowledge of the structure and texture of the rocks jenetrated by the wells.

\section{RESULTS}

\section{GENERAL}

Electric and gamma logs of the wells show that relatively hard beds of rock are present in the aquifer between about 700 and 950 fect below the surface. Relatively soft porous rock is present in the aquifer above and below these hard beds of rock although there are relatively thin beds of hard rock below about 950 feet. Current meter data indicate that little or no water enters the wells 
from the hard zones between 700 and 950 feet. Most of the water enters the wells from soft porous zones between about 500 to 700 feet or between about 950 to 1,200 feet.

Television traverses in the wells showed badly corroded casing in one well and casing not firmly seated and cemented in the aquifer in two wells. An obstruction in one well was shown to be caused by a cave-in of clay above the aquifer. Table 1 lists the wells examined during the investigation, shows the kinds of data collected, and lists the diameter and depth of the well.

\section{ANALYSES OF DATA FROM INDIVIDUAL WELLS}

\section{MAIN STREET WELL FIELD}

WELL NO. 5

(Corner 1st and Laura Streets). This well is reported to be 1,270 feet deep, but instrument probes could not be lowered below 442 feet because of an obstruction in the well bore. The television camera showed that the well is cased to 420 feet, which is about 100 feet above the top of the Floridan aquifer, and that poorly consolidated silty clay below the casing has collapsed and partially blocked the well bore. When the well is discharging, water from the underlying aquifer flows through the restricted opening below the casing at relatively high velocities and carries some silt and clay to the surface in suspension. Figure 2 is a photo of the television screen showing the caved-in zone at a depth of 440 feet in city Well Number 5 .

\section{WELL NO. 7.}

(Hubbard Street and Confederate Park). Electric and caliper logs were run in this well to about 1,229 feet; however, because of technical difficulties the current meter traverse was made to a depth of only 925 feet. The data obtained indicates that about 70 percent of the water flowing from the well at the surface enters the well bore below 925 feet. The data also indicates that no water enters the well between about 750 feet and the bottom of the casing, and in fact some water is lost back into permeable zones in the aquifer between about 700 feet and the bottom of the casing, which is 485 feet below land surface. The caliper $\log$ also shows a probable break in the casing between 90 and 120 feet.

The geophysical logs and a bar graph indicating the percentage of the total natural flow that enters the well at different depth intervals are shown on figure 3.

WELL NO. 13.

(8th Street and Hogans Creek). This well drilled in 1918 is one of the oldest water wells owned by the City. Water has been leaking around the outside of the casing for a number of years, indicating that either the casing is perforated below land surface or the casing is not properly seated in the aquifer and water is leaking upwards around the bottom of the casing. Electric logs were made to locate the bottom of the casing and to obtain geologic and hydrologic information on the rocks penetrated by the well. A television camera traverse was made to inspect the casing seat and to locate any perforations in the casing. 
Table 1. Data obtained from wells.

City

Well

No.

Main Street Well Field

$5 \quad$ 1st \& Laura Sts.

7 Hubbard and

Confederate Park

8th \& Hogan Creek

4th \& Pearl Sts.

Union \& Ionia Sts.

McDuff Well Field

39 Gilmore St. east

of McDuff

12

992

$\mathrm{X}$

Hendricks Avenue Well Field

\section{Total}

Depth

(ft.)

1,270

1,250

1,071

1,242

1,063

Elect
Log



$X$
$X$
$X$
$X$

River Oaks Well Field

$34 \quad$ Pumping Station Yd.
Gamma

Log

Caliper

Log

Current

Meter

Television

Traverse

$\mathrm{X}$

$\mathrm{x}$

$\mathrm{X}$

$\mathrm{X}$

$\mathrm{X}$

$\mathrm{X}$

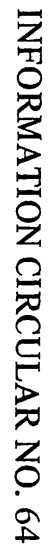

1,286

$\mathrm{X}$

$\mathrm{X}$

$\mathrm{X}$

$\mathrm{X}$

$\begin{array}{lll}1,335 & \mathrm{X}\end{array}$

$\mathrm{X}$ 


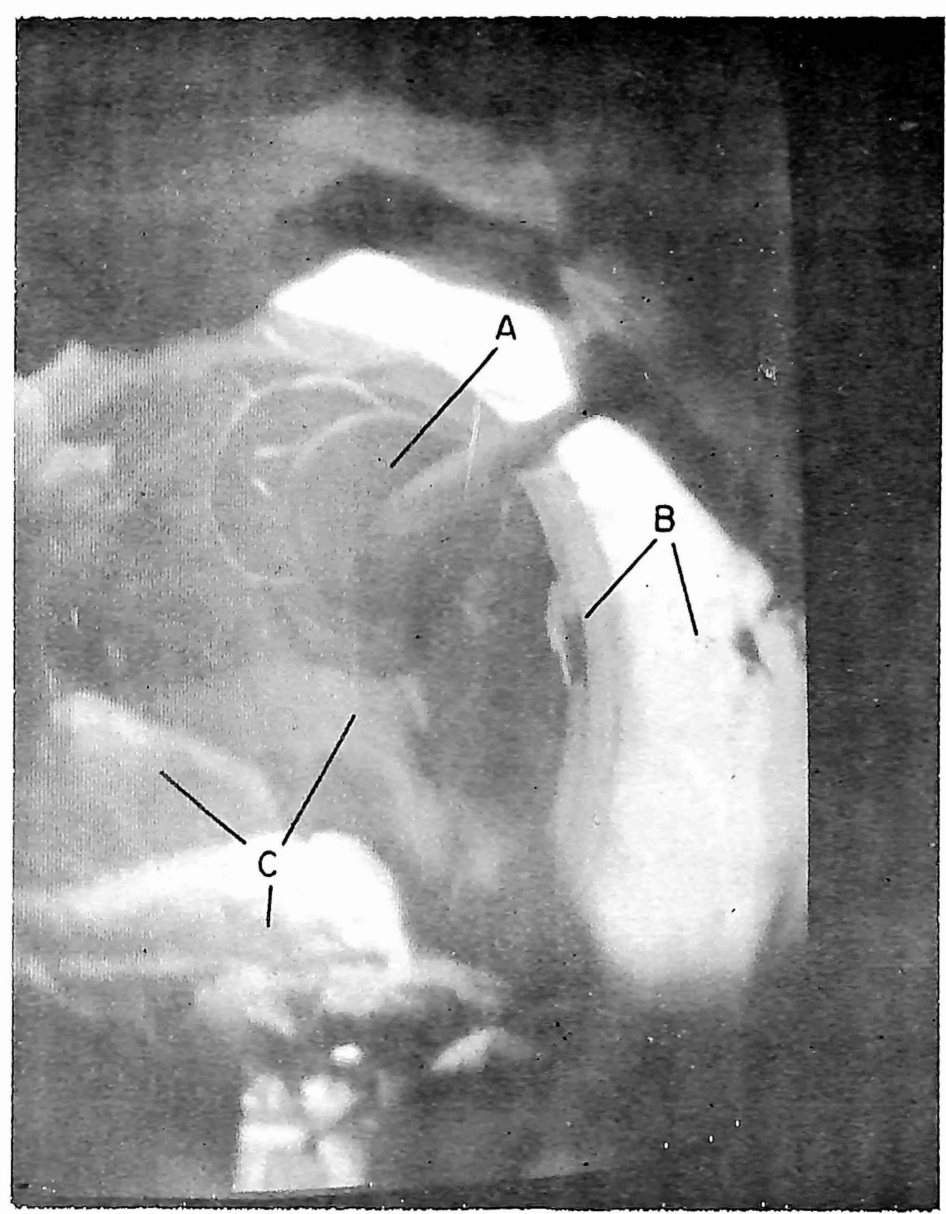

Figure 2. Photograph of television image showing caved-in zone at 440 feet in city well 5 . View looking vertically down into the hole when the television camera was about 3 feet above the caved-in material. A, back of light source; B, smooth side of well bore; $\mathrm{C}$, material which has collapsed into the open hole.

The electric logs and television camera show that the well is cased to about 443 feet below land surface, and that the casing is seated in clay about 60 feet above the aquifer. The television camera shows that the entire casing is badly pitted and corroded and that large longitudinal cracks occur in the casing below about 300 feet below land surface. Water is probably leaking from the casing at many depths below the surface. Although only a small amount of water leaking from the casing reaches the surface, much greater amounts are probably leaking through perforations and cracks in the casing into the surrounding rocks below land surface. Geophysical logs of Well No. 13 are shown on figure 4. 


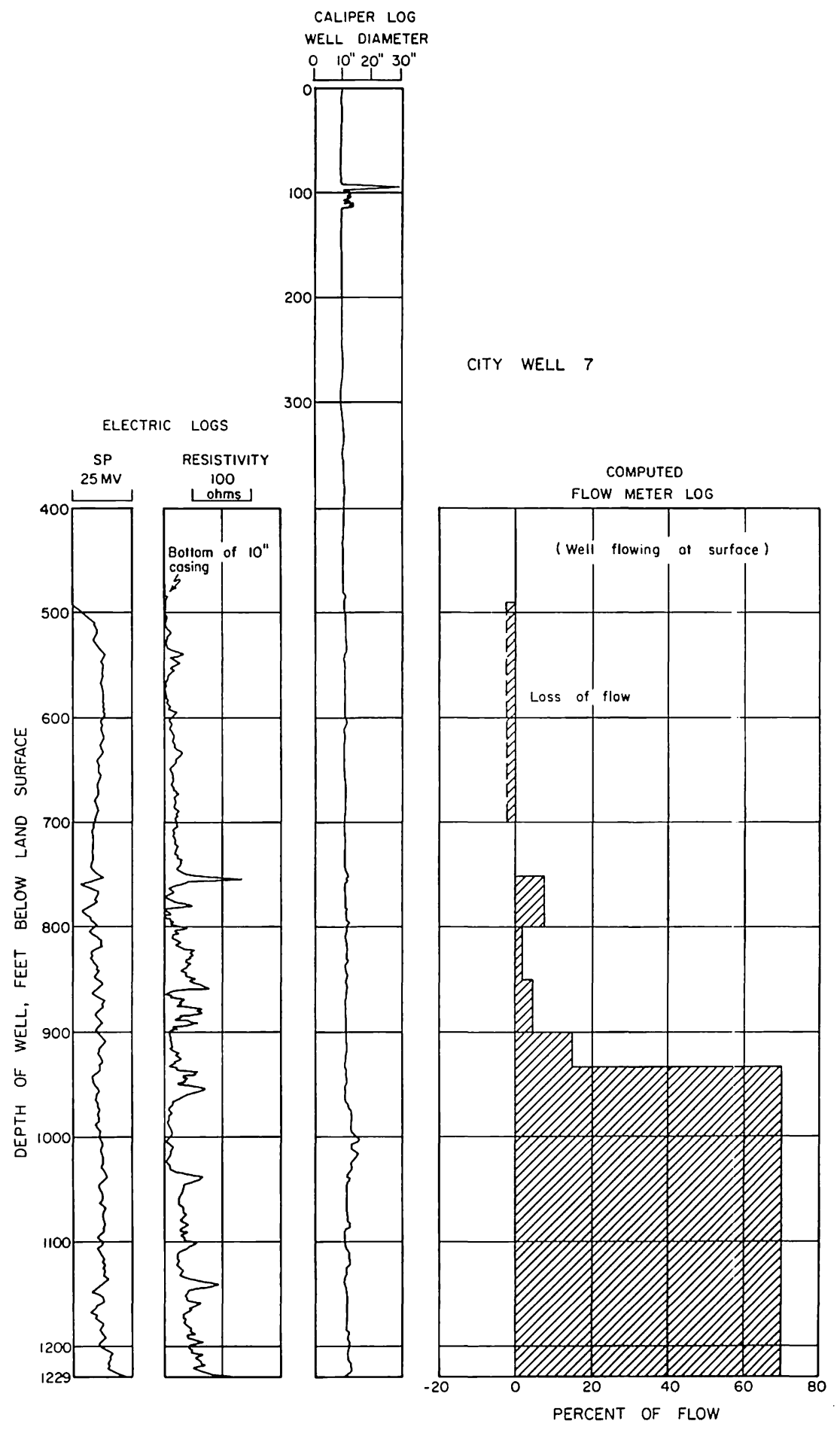

Figure 3. Geophysical data obtained in well no. 7 . 


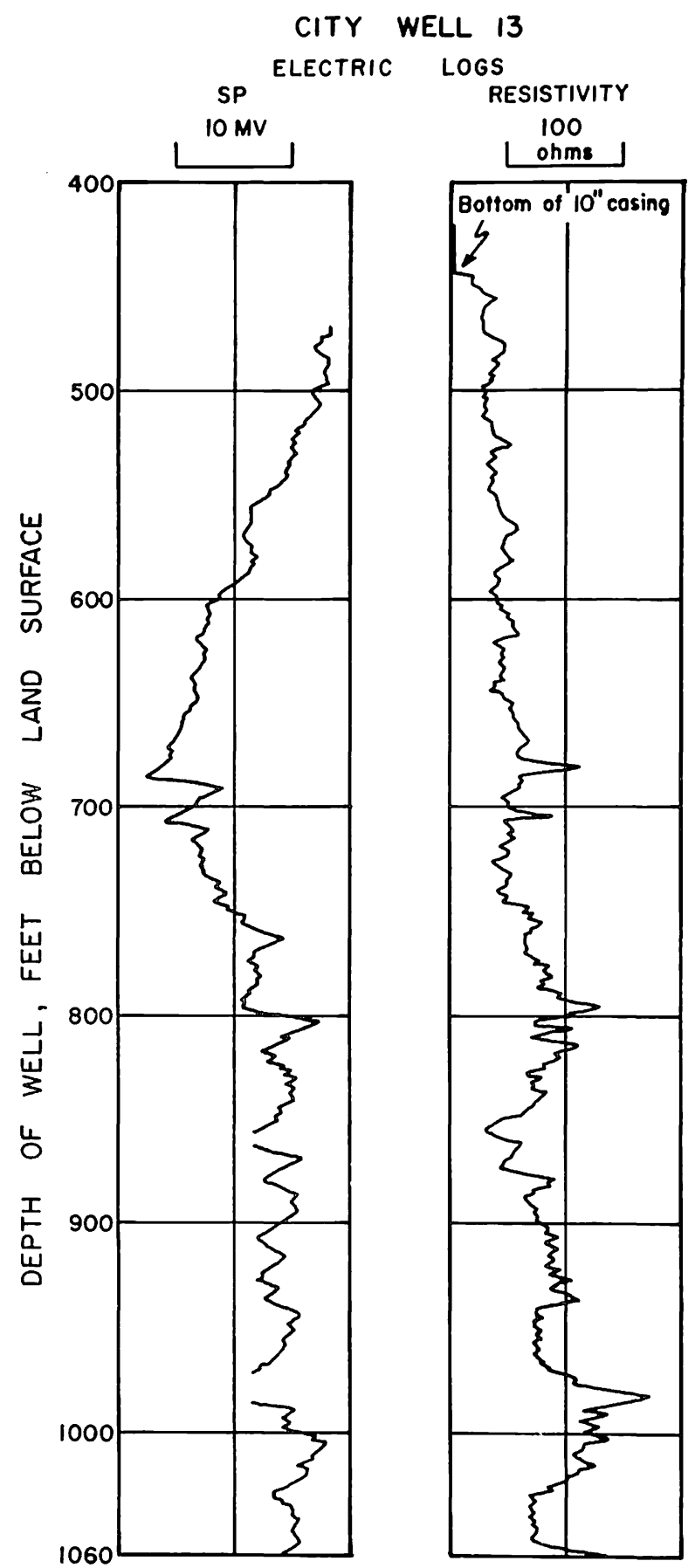

Figure 4. Geophysical data obtianed in well no. 13 . 
WELL NO. 28.

(Corner of 4th and Pearl Streets). This well flows about 900 gallons per minute at land surface. Geophysical data indicates that more than 50 percent of this water comes from soft, porous zones in the aquifer between the bottom of the casing at 498 feet below land surface and about 700 feet below land surface.

Although this well is 1,242 feet deep the data indicates that no water enters the well bore below 1,120 feet. Geophysical and flow meter logs are shown on figure 5.

WELL NO. 44.

(Corner of Union and Ionia Streets). This well flows about 1,070 gpm at land surface. Current meter data indicates that most of this water enters the well bore from two major water-bearing zones, between about 550 and 700 feet below land surface and below about 900 feet. The zones above 550 feet and between 700 and 900 feet yield only small quantities of water.

Electric logs indicate numerous alternating soft, porous and hard, nonporous zones occur in the aquifer between 780 and 940 feet below land surface. The caliper $\log$ and the television camera indicate that there are many small cavities or fractures in the rock between these depths. Geophysical and flow meter logs are shown on figure 6 .

\section{MCDUFF WELL FIELD}

WELL NO. 39.

(On Gilmore Street east of McDuff Avenue). The water from this well contains large quantities of green clay and sand. Geophysical and television explorations were made in the well to locate the source of this sediment. The logs and television data show that the casing of this well is seated in limestone at the top of the Floridan Aquifer about 500 feet below land surface. About 1 to 2 feet below the bottom of the casing there is a cavity about 8 feet in height and at least 14 inches larger in diameter than the diameter of the casing. This cavity is the probable source of the sand and clay. Water entering the well bore through this cavity is probably carrying in poorly consolidated material from above the top of the limestone. The television camera showed that while the well was flowing, large quantities of sand were being held in suspension in the well bore below the cavity. When this sand enters the well bore through the cavity, the lighter particles are carried to the surface when the well is flowing and the heavier particles either drop to the bottom of the well or are held in suspension in the bore. When the well is pumped the water moves up the well bore at faster velocities and carries these heavier particles to the surface in suspension. Current meter data indicates that 70 percent of the water discharged at the surface by gravity flow enters the well from this cavity, and that no water enters the bore between 810 feet and the bottom of the well at 992 feet (the last 180 feet). Geophysical logs and current meter data are shown in figure 7 . 


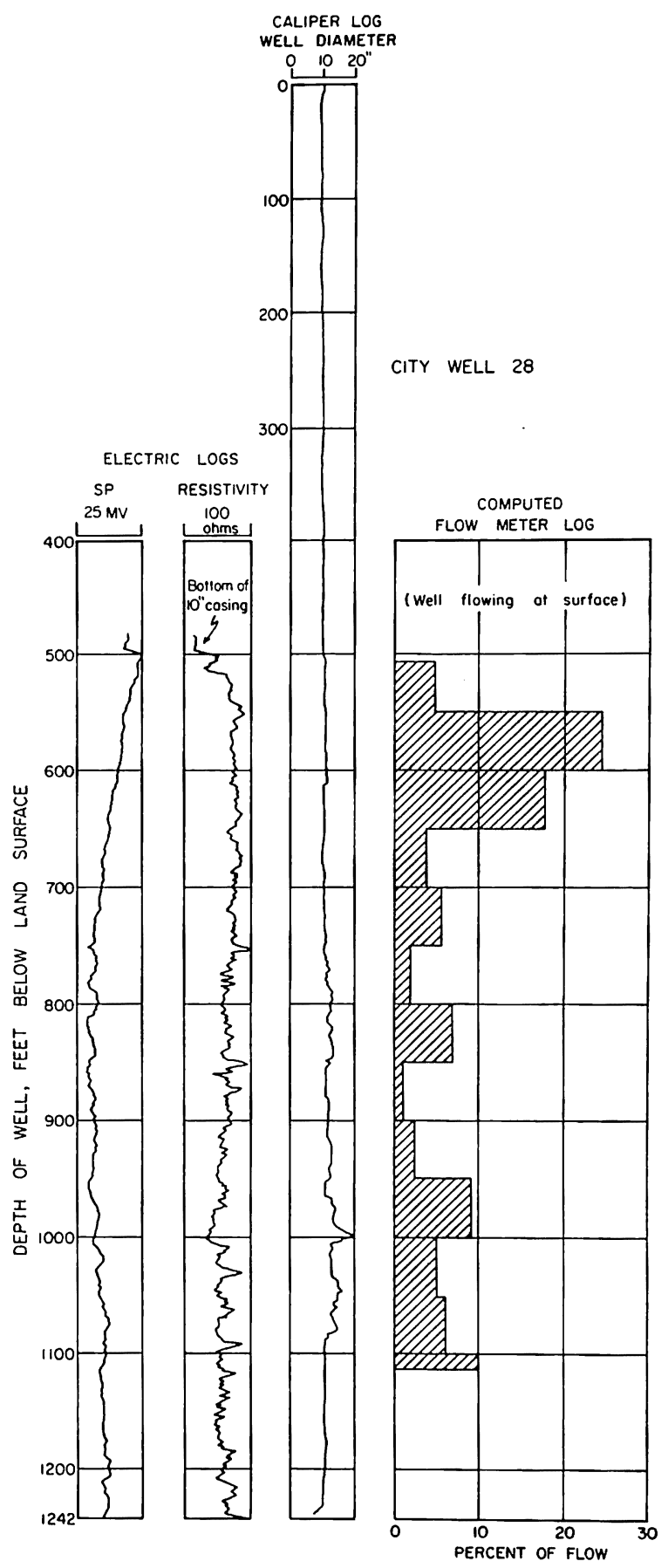

Figure 5. Geophysical data obtained in well no. 28 . 


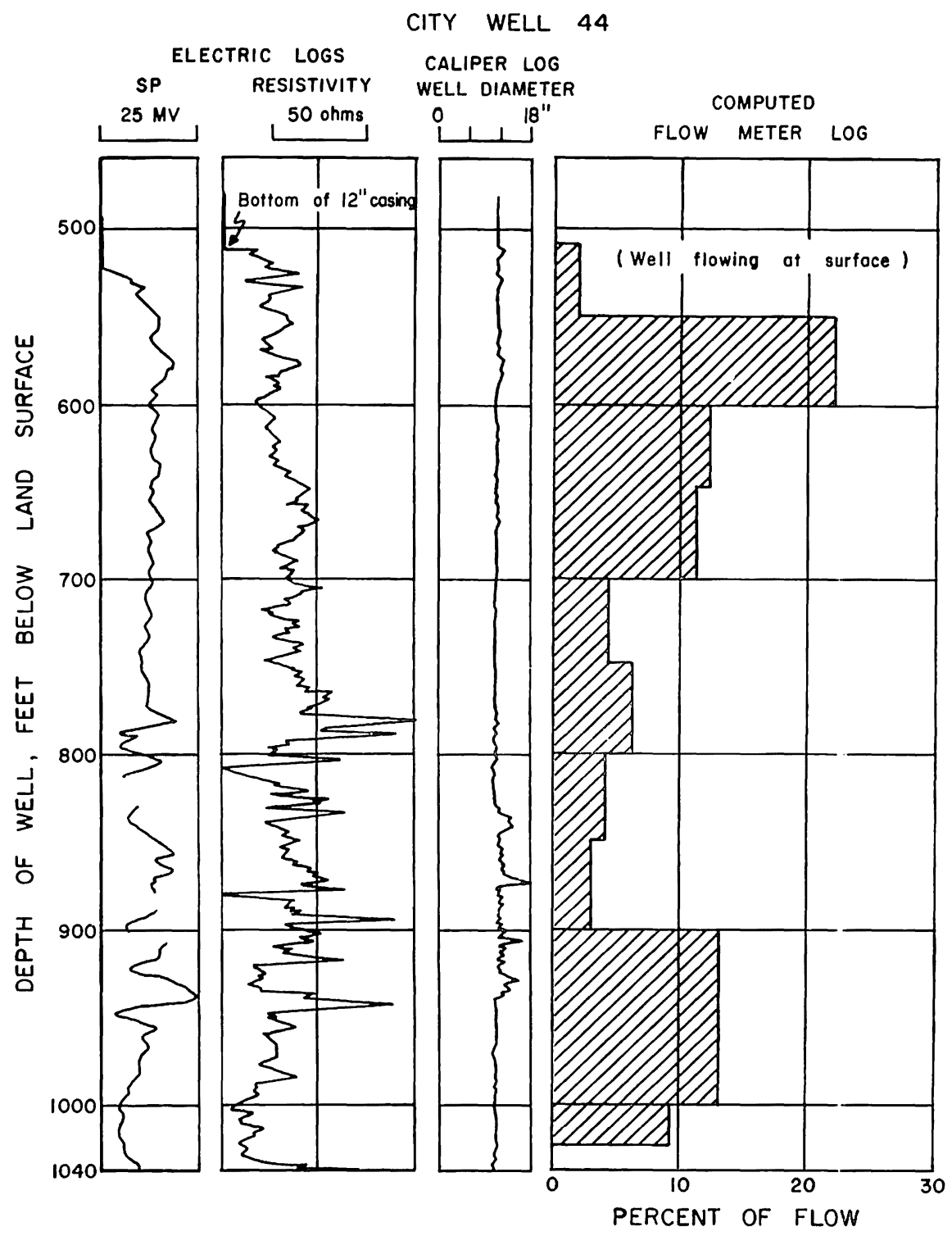

Figure 6. Geophysical data obtained in well no. 44. 

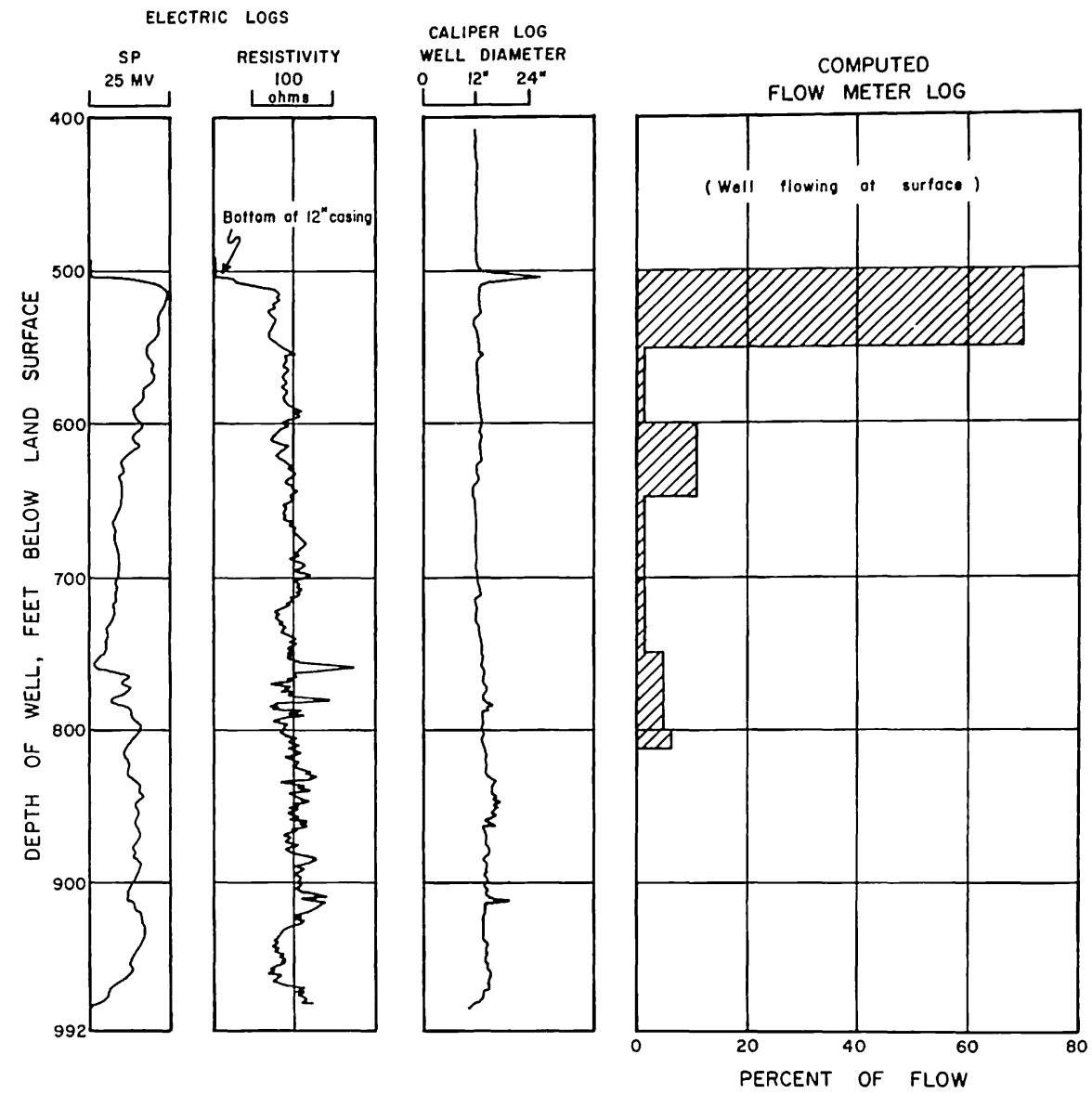

Figure 7. Geophysical data obtianed in well no. 39 .

\section{HENDRICKS AVENUE WELL FIELD}

WELL NO. 35.

(On LaRue Street between Nira and Cedar Streets).This well flows 1,200 gpm and current meter data indicates that more than 80 percent of this water enters the well from two major water-producing zones in the aquifer: between the bottom of the casing at 508 feet and about 750 feet below the surface and between about 1,150 feet and 1,250 feet below the surface. Only a relatively small amount of water enters the well in the intervals between about 750 and 950 feet and between 1,050 feet and 1,150 feet below the surface. The electric logs show relatively large increases in resistivity in these non-producing zones, which indicates that the rocks in these zones are relatively hard and impermeable. Geophysical logs and flow meter data are shown in figure 8. 


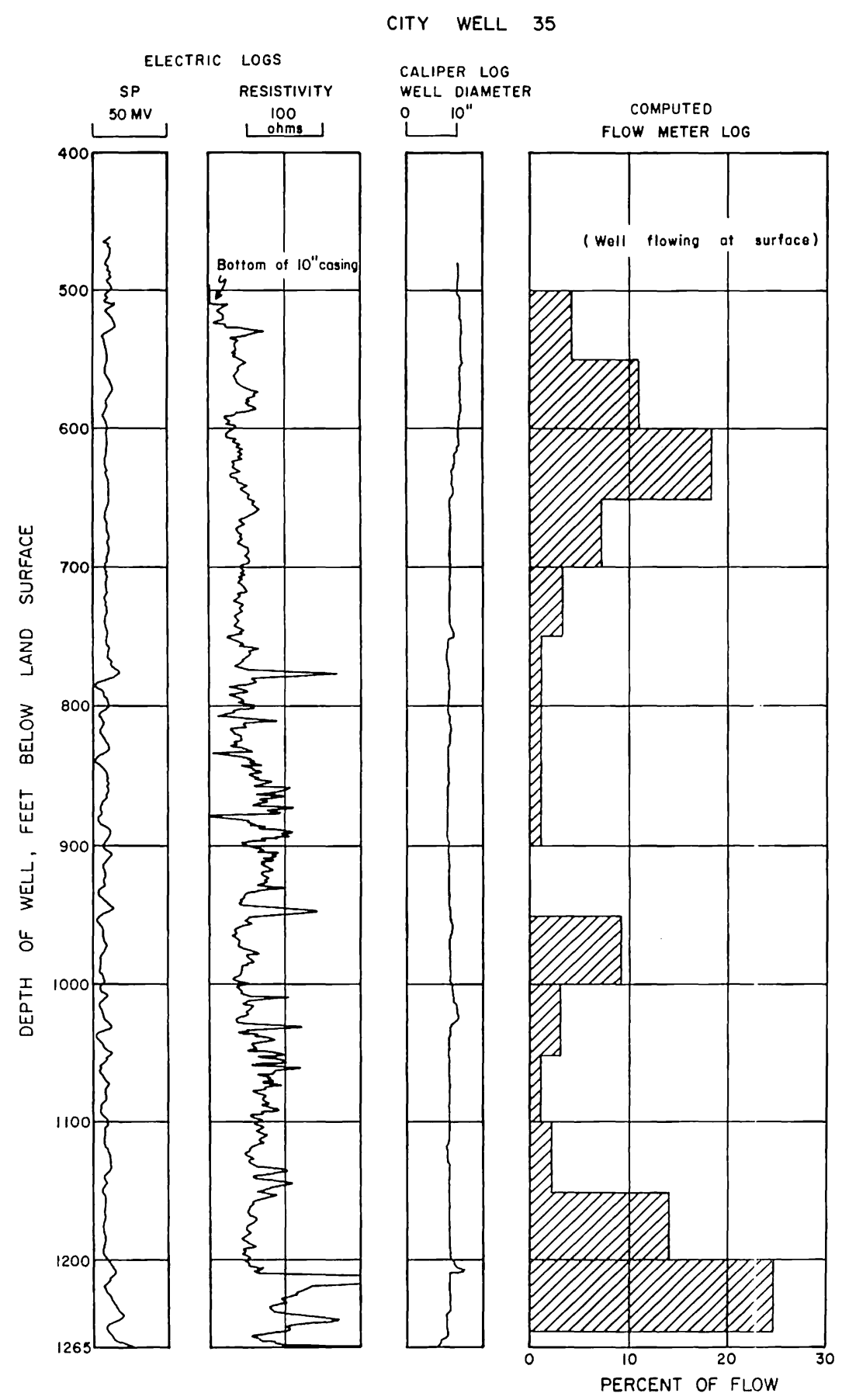

Figure 8. Geophysical data obtained in well no. 35 . 


\section{RIVER OAKS WELL FIELD}

WELL NO. 34.

(In River Oaks Pumping Station yard). Current meter data shows that while the well is flowing at the surface all of the water enters the well from below 900 feet beneath land surface. These data also indicate that there is internal circulation of water in the well bore and some of the water that enters the well below 900 feet is lost back into the aquifer between about 800 feet and the bottom of the casing at 508 feet. Although the loss of water is slight while the well is flowing at the surface a current meter traverse made while the well was closed at the surface shows that a comparatively large quantity of water from below 900 feet is lost back into the aquifer above 800 feet. Current meter data in fig. 9 also shows that no water enters the well bore below about 1,240 feet and the bottom of the well at 1,335 feet (the last 95 feet). Geophysical logs and current meter data are shown on figure 9. 


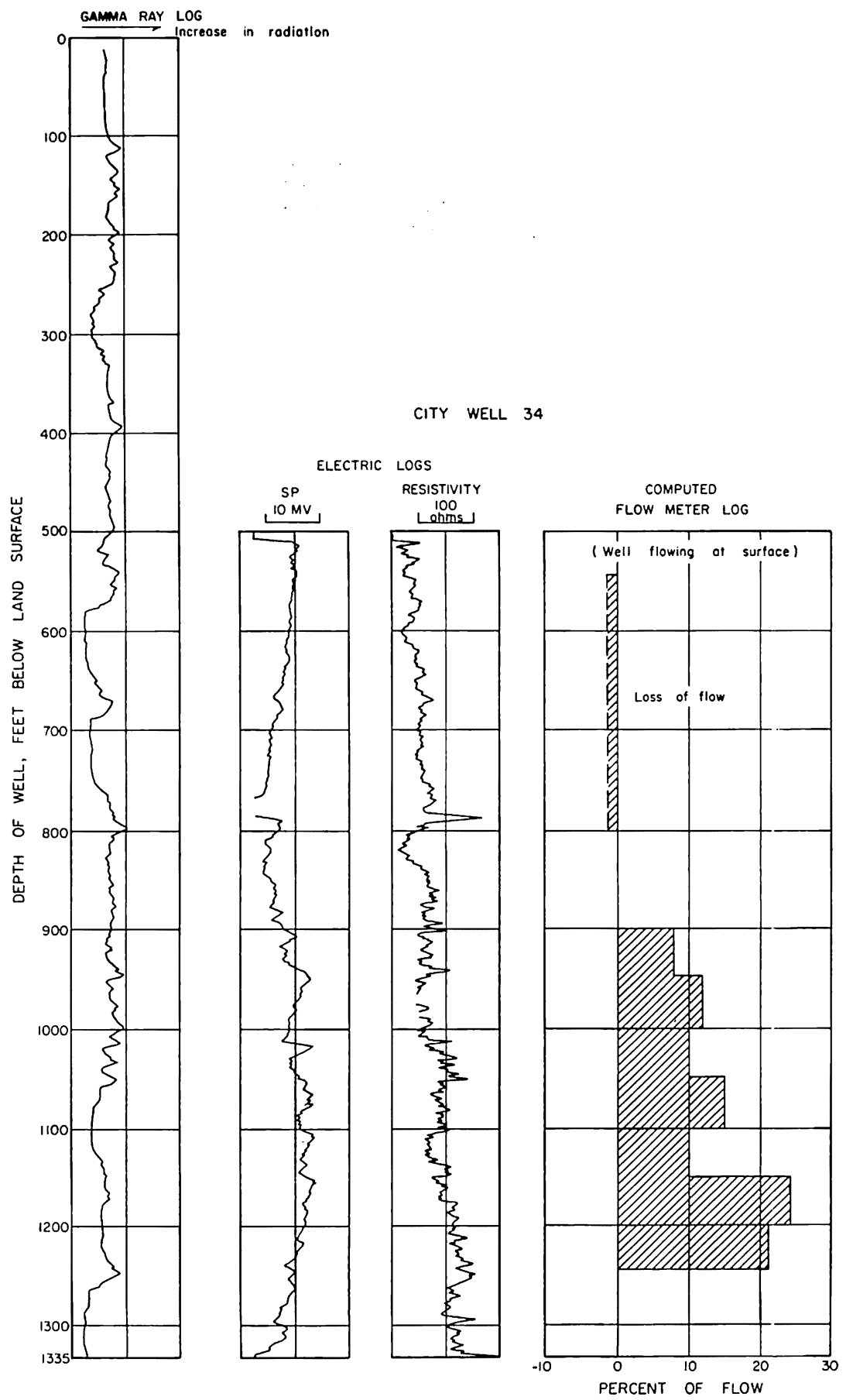

Figure 9. Geophysical data obtained in well no. 34 . 


